\title{
Integration of Geophysics and Remote Sensing Techniques in Mapping Zones Mineralised with Disseminated Gold and Sulphide Minerals in Lolgorien, Narok County, Kenya
}

\author{
Sammy O. Ombiro ${ }^{1}$, Akinade S. Olatunji ${ }^{2}$, Eliud M. Mathu ${ }^{3}$ and Taiwo R. Ajayi ${ }^{4}$ \\ ${ }^{I}$ Pan African University, Life and Earth Sciences Institute, University of Ibadan, Ibadan, Nigeria. \\ E-mail: sombiro@jkuat.ac.ke \\ ${ }^{2}$ Department of Geology, University of Ibadan, Ibadan, Nigeria. E-mail: \\ akinadeshadrach@yahoo.com \\ ${ }^{3}$ Department Geology and Meteorology, South Eastern Kenya University, Kitui, Kenya. E-mail: \\ emathu@seku.ac.ke \\ ${ }^{4}$ Department of Geology, University of Ibadan, Ibadan Nigeria. E-mail: traajai66@ gmail.com \\ * Corresponding author \\ Received 13 Jan 2021, Revised 18 May 2021, Accepted 19 May 2021, Published May 2021
}

DOI: https://dx.doi.org/10.4314/tjs.v47i2.31

\begin{abstract}
Even though ground geophysical surveys (especially Induced polarization and resistivity) are applied in mineral exploration, their effectiveness in identification of mineralised zones is often enhanced by integrating other mineral exploration techniques such as remote sensing and geological investigations. Integrating different techniques helps in reducing uncertainty that is often associated with mineral exploration. The methods being integrated also depend on characteristics of mineralisation and those of host rock. In this study, geophysical survey methods (induced polarization and resistivity) were integrated with remote sensing and geological methods to delineate mineralised zones in Lolgorien beyond reasonable doubt. By integrating these methods, it was found that Lolgorien's gold and sulphide minerals (disseminated minerals) are hosted in massive quartz veins and auriferous quartz veins hosted in Banded Iron Formations. It was also found that this mineralisation was controlled by faults which mainly trend in two directions (NW-SE) and (NE-SW).
\end{abstract}

Keywords: hydrothermal alteration, chargeability, resistivity, band ratio, lineament density

\section{Introduction}

Geo-spectral, geophysical, geochemical, geological structures and lithographic properties of rocks and mineralised zones are often exploited by geoscientists in search of valuable ore bodies. This is because mineralised zones often exhibit anomalous geo-spectral, geochemical, gravitational, geoelectric, geo-magnetic, geological structures and lithographic properties which make their delineation possible (Lowrie and Fichtner 2020).
Geo-electric properties of subsurface structures are often examined using induced polarization (IP) surveys, electrical resistivity surveys and electromagnetic surveys. Geological studies are often done using remote sensing, field mapping and petrographical studies. The variations in spectrum properties can be examined using remote sensing techniques. It is, however, important to note that locating mineralised zones is often associated with uncertainties as it is often difficult to know with $100 \%$ certainty the 
spatial extents of an ore body (Ombiro and Akisa 2016). Because of this uncertainty, using one technique is never enough in locating areas of possible mineralisation. To reduce this uncertainty (that is, to prove beyond reasonable doubt) and depending on the characteristics of mineralisation and host rock, the aforementioned techniques are often integrated (Auken et al. 2006, Vallee et al. 2011).

Many studies and exploration programmes have been conducted in the past integrating these techniques. For example, Sultan et al. (2009) integrated geochemical exploration and geophysical survey techniques to explore for gold in Wadi El Beida area, South Eastern Desert, Egypt. From this study, an integrated map showing potential areas for drilling program was produced. Integration of these exploration methods showed that alteration shear zones which are associated with gossans host disseminated sulphides and gold mineralisation. Gaafar (2015) integrated geochemical, geological, mineralogical and geophysical data to delineate mineralised zones in Um Naggat area, Central Eastern Desert, Egypt. From the aeromagnetic data (geophysical data), four structural trends were delineated (NW, NNW, E-W and ENE). According to Gaafar (2015), these structures were potential pathways through which mineralised fluids may have migrated and thus they played important roles in mineralisation. Abedi and Norouzi (2012) integrated various geophysical data (magnetic, resistivity and IP data) with geochemical, remote sensing and geological data to determine areas that may require drilling for exploration of copper in Kerman province, Iran. The study found that copper mineralisation in this area was generally associated with hydrothermally altered rhyodactic unit which trends in NE-SW direction. Waswa (2015) integrated remote sensing, geophysics, geological and geochemical investigations in mapping areas of possible iron ore mineralisation in MutomoIkutha area, South East Kenya. By integrating these data, Waswa (2015) were able to show that iron ore mineralisation (magnetite) in Mutomo-Ikutha Area, South East Kenya is generally associated with fault structures, and the mineralisation is generally oriented in the same direction as the trend of faults.

Many studies such as those of Sultan et al. (2009), Ariyibi (2011), Abedi and Norouzi (2012), Gaafar (2015), Waswa (2015) and Ogungbemi et al. (2018) have been carried out around the world integrating geophysical, geochemical and remote sensing techniques in mapping and delineating potential ore bodies. However, such integrated studies especially the ones integrating remote sensing and traditional techniques (such as geophysics and geological) had not been carried out in Lolgorien, Narok County, Kenya to the best knowledge of the authors. This is despite the fact that the area has been dominated with gold mining artisanal miners (AMS) for a long period of time. This study integrates remote sensing, geological and geophysical techniques to map areas of possible mineralisation and structures that may be associated with the mineralisation.

\section{Location of the study area}

Lolgorien (the study area) is located in Western part of Kenya in Narok County (Figure 1). The area is located within the East Africa's Great Rift Valley. It is geographically located between $1^{\circ} 09^{\prime} 0$ " $\mathrm{S}$ to $1^{\circ} 15^{\prime} 0^{\prime \prime} \mathrm{S}$ and $34^{\circ} 44^{\prime} 0^{\prime \prime}$ $\mathrm{E}$ to $34^{\circ} 55^{\prime} 0^{\prime \prime} \mathrm{E}$. The area receives moderate to high rainfall resulting into high to moderate vegetation cover. The location of the study area with respect to Kenya and Narok County is shown in Figure 1. 


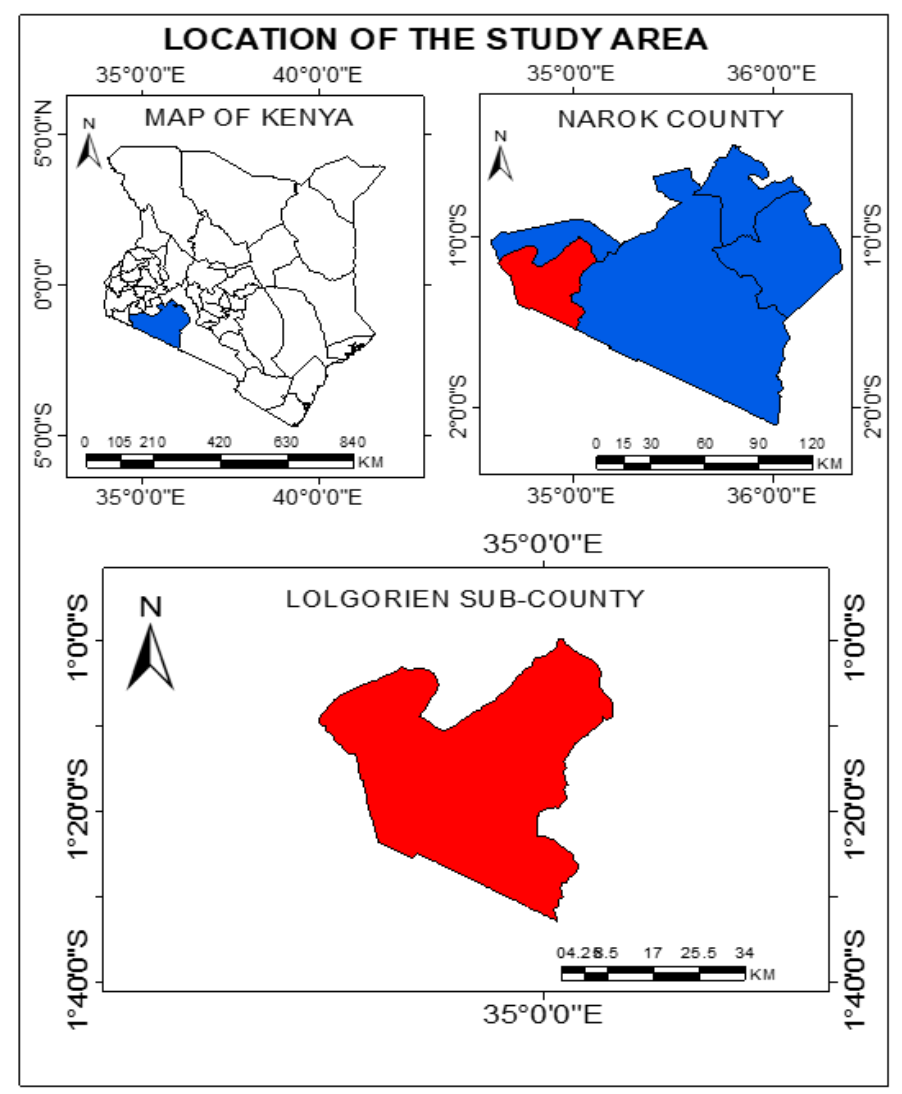

Figure 1: Location of study area with respect Narok County and Kenya.

\section{Geological settings}

The study area is located in Archean geological system which is found in Western Kenya. The Archean geological system is divided into Nyanzian and Kavirondian geological systems which form part of the larger Tanzanian craton (Shackleton 1946, Ichang'i and MacLean 1991, Henckel et al. 2016). The Nyanzian system mainly consists of following rock units: lavas, banded iron formations (BIF), pyroclastics, minor sediments, cherts, iron stones, basalts and shale (Akech et al. 2013). The Kavirondian system which lies on top of the Nyanzian system, mainly consists of conglomerates, sandstones, grit and greywacke (Akech et al. 2013). These rock units generally trend in the North WestSouth East directions (as shown in Figure 2), and are generally isoclinally folded with the axes of the folds trending in the East-West direction (Shackleton 1946, Ichang'i and MacLean 1991, Murray-Hughes 2007).

The Western Kenyan Archean geological system is an extension of Tanzanian craton where base and precious metal mineralisation occur (Akech et al. 2013). Metallic minerals such silver, gold and copper have been found in the region, and because of this, a number of active and abandoned mines are found throughout the area. The geological map of the study area (Lolgorien) is shown in Figure 2. 
Tanz. J. Sci. Vol. 47(2), 2021

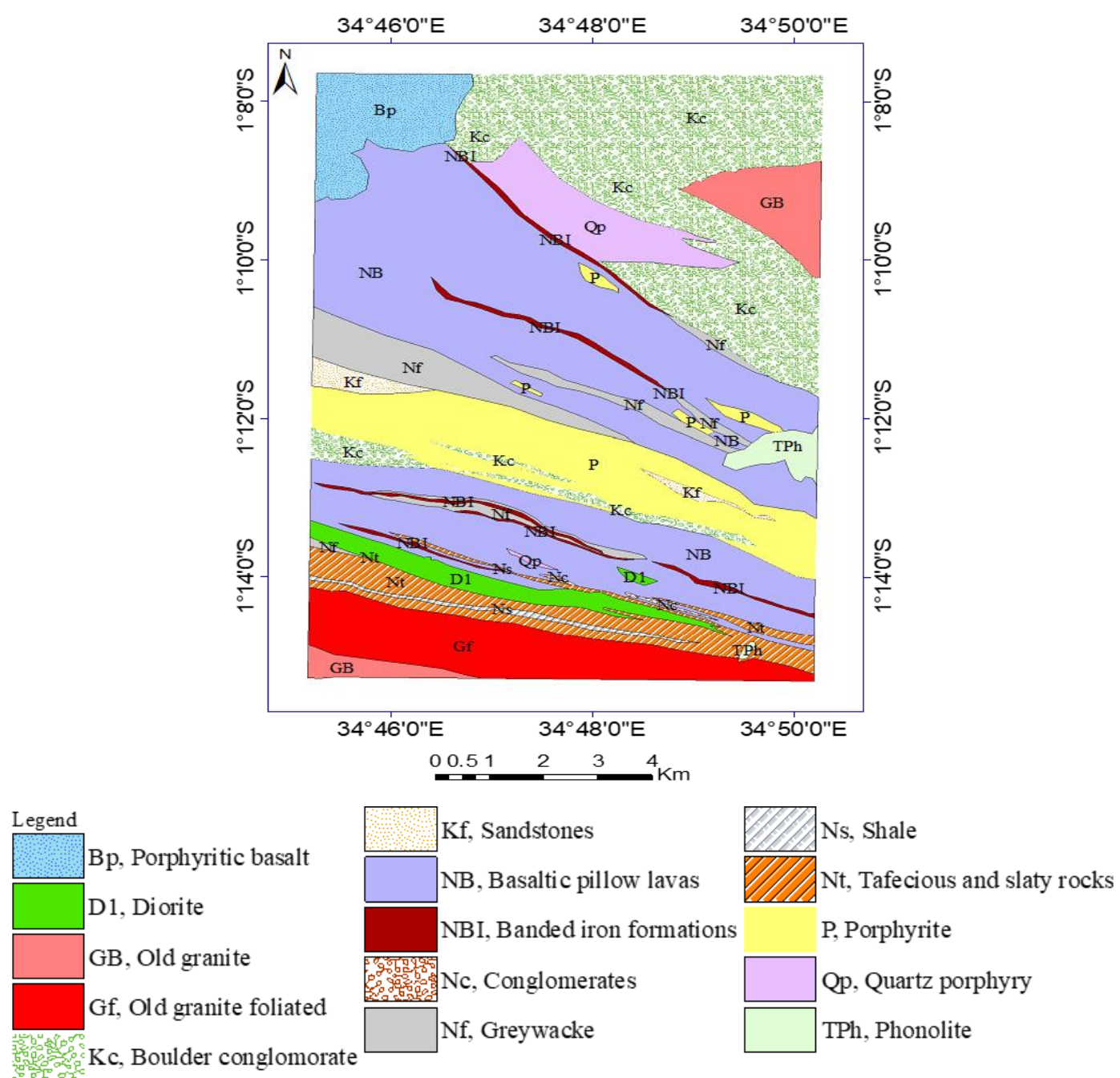

Figure 2: Geological map of Lolgorien.

\section{Materials and Methods}

The mineral exploration exercise begun with remote sensing which was carried out to delineate areas of possible hydrothermal alterations and to map geological structures which may be associated with or controlling mineralisation in the area of study. This was followed by geophysics exercise which consisted of IP and resistivity surveys. The geophysics survey was carried in areas delineated (identified) by remote sensing as areas of possible hydrothermal alterations.
Remote sensing mapping mineralised zones

Remote sensing was used to map lineaments that control Lolgorien's mineralisation and areas of possible hydrothermal alterations. Lineaments were extracted using Shuttle Radar Topography Mission (SRTM) image downloaded from the United States Geological Survey (USGS) website and subjected to hillshade analysis (100/60; 315/45 and 200/50) where lineaments and structures were revealed and extracted. The 
extracted lineaments are shown in Figure 3. Hillshade analysis was carried out in ArcMap, and lineaments were extracted manually from the hillshaded images. From the lineaments, lineament density map was also extracted using ArcMap. Rose diagrams were developed using Rockworks software.

Delineation of the hydrothermal alteration zones was done using band ratio and band ratio composite (Sabin's ratio and Kaufmann's ratio) analyses in ArcMap. Two band ratios images $(6 / 5$ and $7 / 5)$ were produced as shown in Figures $4 \mathrm{~A}$ and B, respectively. The Sabin's ratio $(4 / 2,6 / 7,6 / 5)$ and Kaufmann's ratio (7/5, $5 / 4,6 / 7$ ) images are shown in Figure $4 \mathrm{C}$ and $\mathrm{D}$, respectively. It is important to note that $6 / 5$, $7 / 5$, Sabin's and Kaufmann's band ratios are mainly used in mapping zones of possible hydrothermal alterations and iron-rich minerals from unaltered rocks and vegetation (Han and Nelson 2015).

\section{Geophysics mapping mineralised zones}

As already mentioned above, the zones identified and delineated as areas of possible hydrothermal alterations were subjected to IP and resistivity surveys. These areas are enclosed in rectangular boxes shown in Figures 3 and 4. The readings associated with IP and resistivity surveys were performed through chargeability and resistivity in time-domain from a set of parallel survey lines (transects) with distance that ranged from $5 \mathrm{~m}$ to $23 \mathrm{~m}$ between the electrodes and $25 \mathrm{~m}$ between the lines. The spacing between electrodes was influenced by the difficulty to access some areas covered by thick vegetation or rough terrain. As a result of this, the survey layout was planned based on the characteristics of the delineated zone such as topography, ease of access and the size area to be mapped.

The geophysics survey data was acquired using Zonge GGT-3 transmitter that was powered using a 3-phase generator and a Scnitrex time-domain receiver (IPR12). The data acquired by the Scnitrex time-domain receiver were processed using Oasis Montaj (Geosoft) software to produce overall resistivity and chargeability gradient maps (Figure 5 and 6, respectively) and using Res2dinv software for inversion of the data (Figures 7 to 11 ).

\section{Results and Discussion \\ Remote sensing data and analysis \\ Delineated structures (lineaments) that control mineralisation}

Figure 3 shows the extracted lineaments, lineament density map and rose diagram for the lineaments. A zone with the highest concentrations of lineaments in accordance with the lineament density was delineated since the higher the number of lineaments, the higher the chances of mineralisation. This zone is enclosed in a blue rectangular box shown in Figure 3B. 

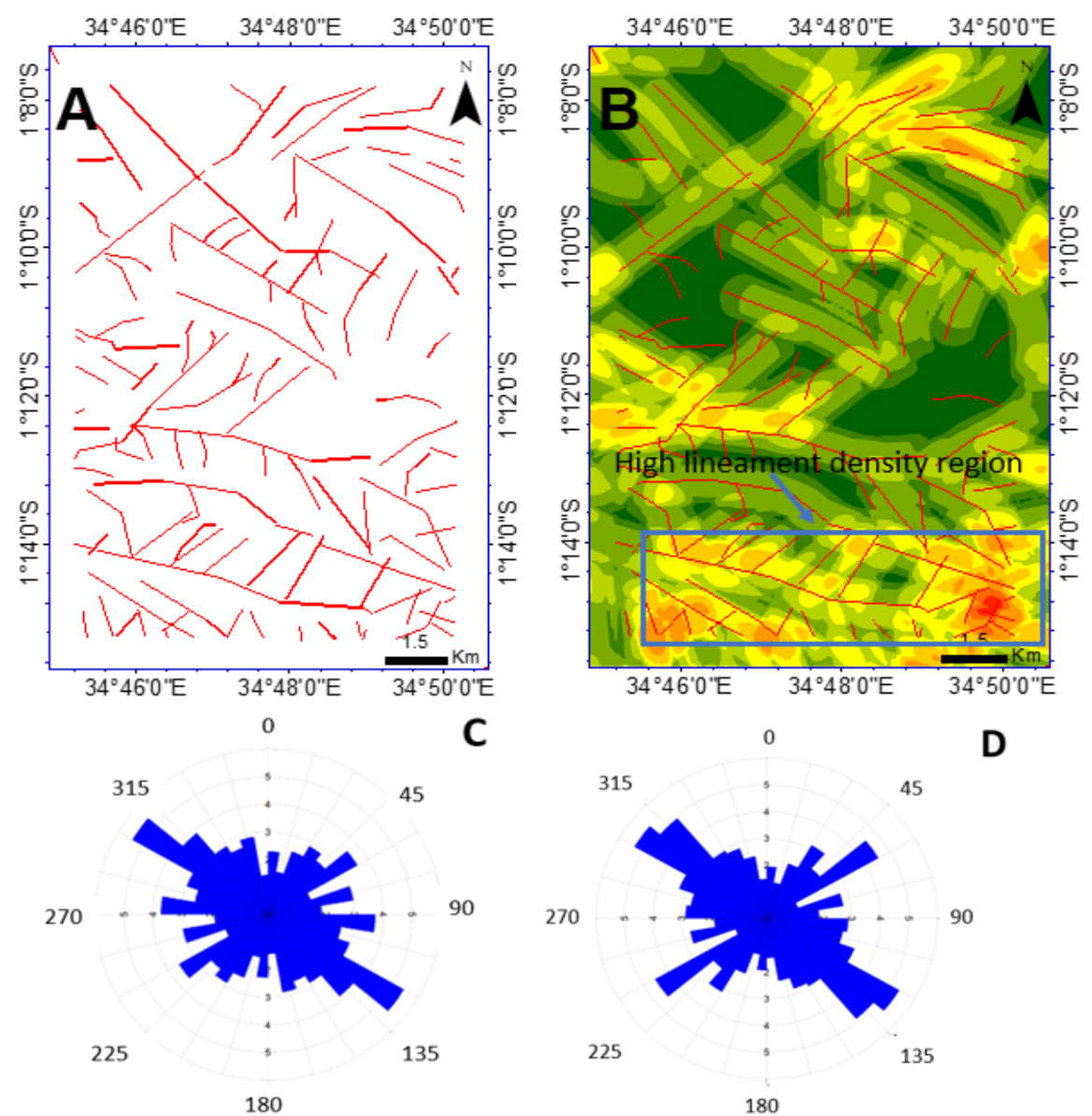

Figure 3: Extracted lineaments (structures), Lineament density map and Rose diagrams. A) the lineaments extracted from the hillshade images. B) Lineament density map. C) Lineament frequency (number of lineaments) rose diagram. D) Lineament length rose diagram.

\section{Mapping of areas of possible hydrothermal alterations}

Figures $4 \mathrm{~A}$ to $4 \mathrm{D}$ show results of band ratio analysis. Figure $4 \mathrm{~A}$ is the result for $6 / 5$ band ratio analysis; Figure $4 \mathrm{~B}$ is the result for $7 / 5$ band ratio analysis; Figure $4 \mathrm{C}$ is the result for Sabin's band ratio analysis; and Figure 4D is the result for Kaufmann's band ratio analysis. The zones with the highest probability of hosting hydrothermal mineralisation and iron rich minerals were delineated and enclosed red and black rectangular boxes shown in Figures $4 \mathrm{~A}$ to $4 \mathrm{D}$. These zones are associated with bright pixels in Figures $4 \mathrm{~A}$ and $4 \mathrm{~B}$, by blue pixels in Figure $4 \mathrm{C}$, and by red and rose colours in Figure 4D. The zone delineated to be having the highest density of lineaments (faults) turns out to be the same zone delineated as having possibility of being associated with hydrothermal alterations and iron rich minerals (see rectangular enclosures in Figure $3 \mathrm{~B}$ and Figures $4 \mathrm{~A}$ to $4 \mathrm{D}$, respectively). This shows that mineralisation (hydrothermal alteration) in Lolgorien is controlled by faults. Some of these faults trend in the NW-SE direction and others trend in the 
NE-SW direction as shown in Figures $4 \mathrm{C}$ and 4D.

Structures (lineaments) especially faults usually act as potential pathways through which mineralised fluids migrate, and thus
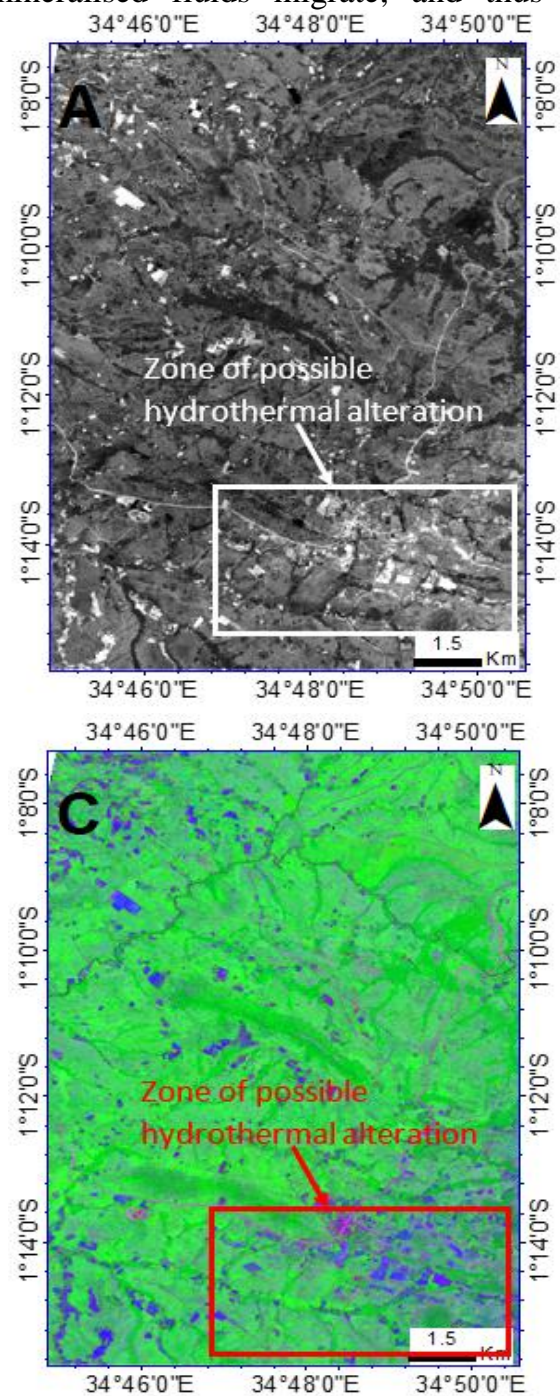

Figure 4: $6 / 5$ band ratio (A), 7/5 band ratio (B), Sabin's band ratio (C) and Kaufmann's band ratio (D).

\section{Resistivity maps of hydrothermal zones} Resistivity and chargeability gradient maps The resistivity and chargeability gradient maps of hydrothermal zones are shown in Figures 5 and 6. playing an important role in mineral occurrences (Gaafar 2015). Therefore, zones of mineralisation in Lolgorien occur along the clustered fault network.

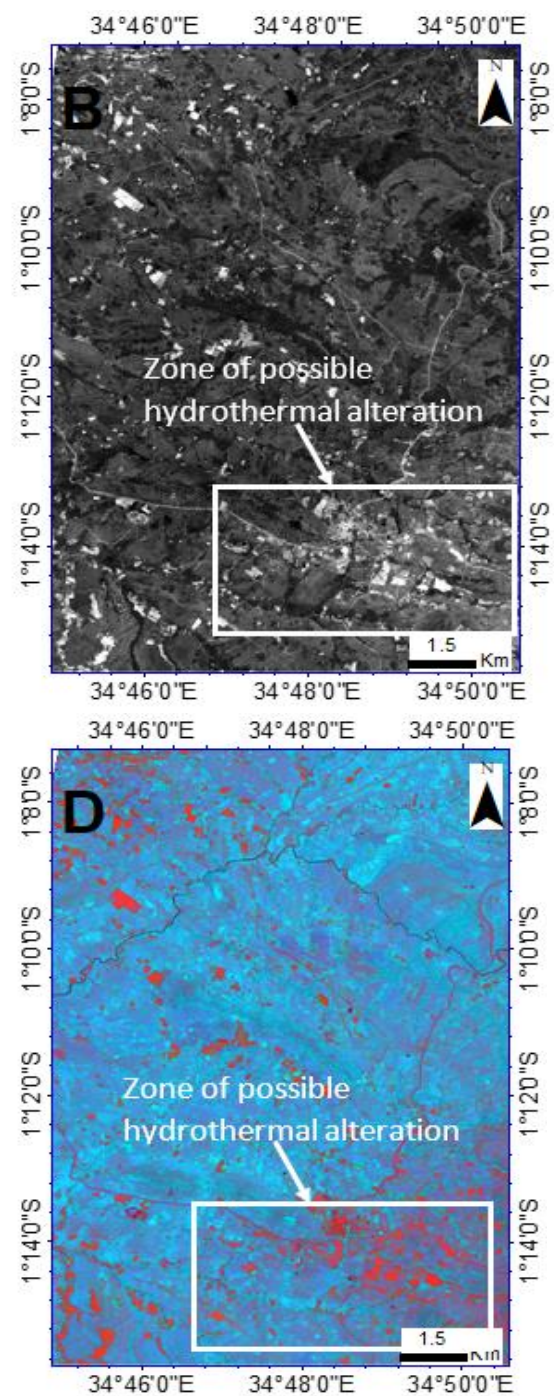

Using Oasis Montaj software, the gradient IP and resistivity data were plotted into colour coded gradient maps as shown in Figure 5 (resistivity gradient map) and Figure 6 (chargeability gradient map). These maps show 
resistivity and apparent chargeability values of the delineated area. From the two maps, it is observed that zones associated with high resistivity are also associated with high values of apparent chargeability. This means that there is a possibility of presence disseminated minerals hosted in rocks with high electrical resistance which is typical to hydrothermal alteration (Fon et al. 2012, Moreira et al. 2016). These include disseminated gold, pyrite and chalcopyrite minerals hosted in a massive quartz vein (Fon et al. 2012, Moreira et al. 2016). The high chargeability is as result of the presence of disseminated minerals, while high resistivity is as result of quartz vein that was found in the vicinity (Figure 8A).

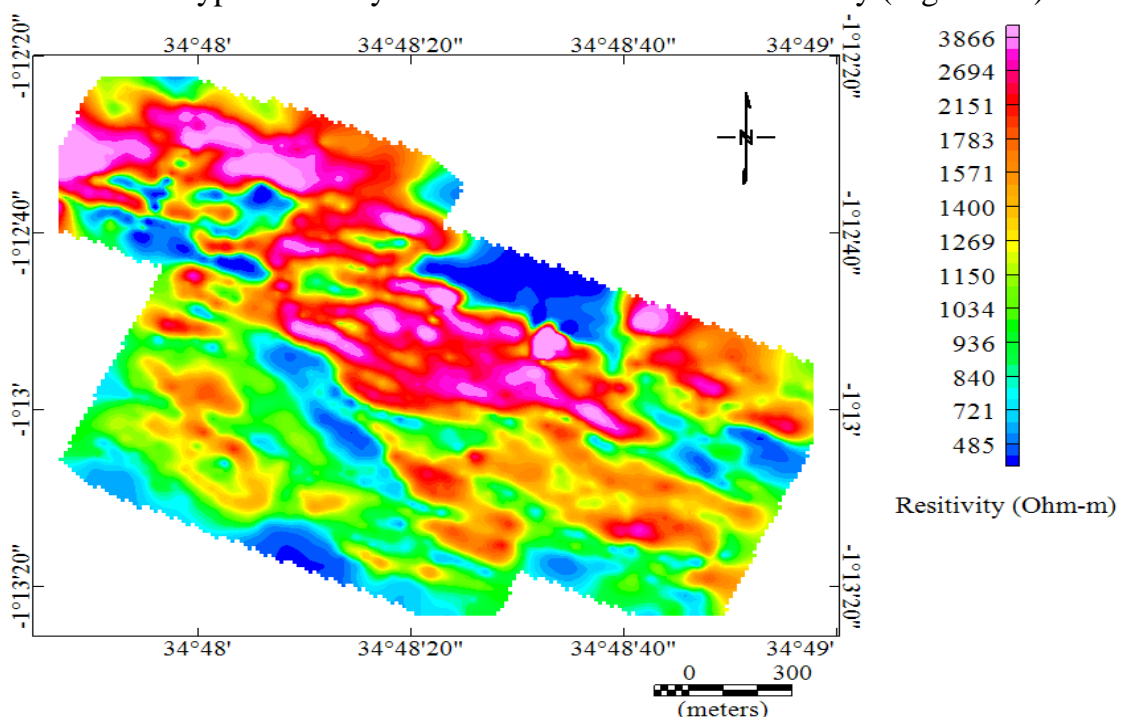

Figure 5: Total resistivity map of the zones with possible mineralisation.

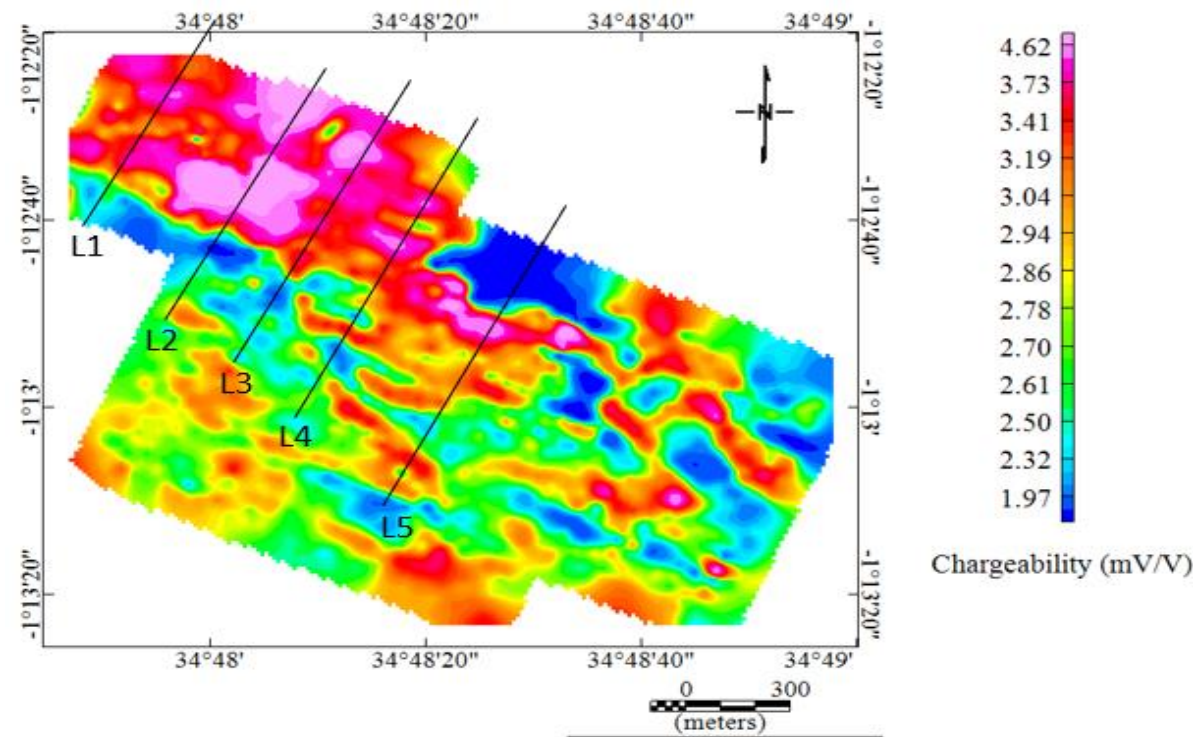

Figure 6: Total chargeability map of zone of possible mineralisation. 


\section{Inversion model along survey line 1 (L1)}

Figure 7 shows an inversion model for the resistivity and chargeability data collected along survey line L1.

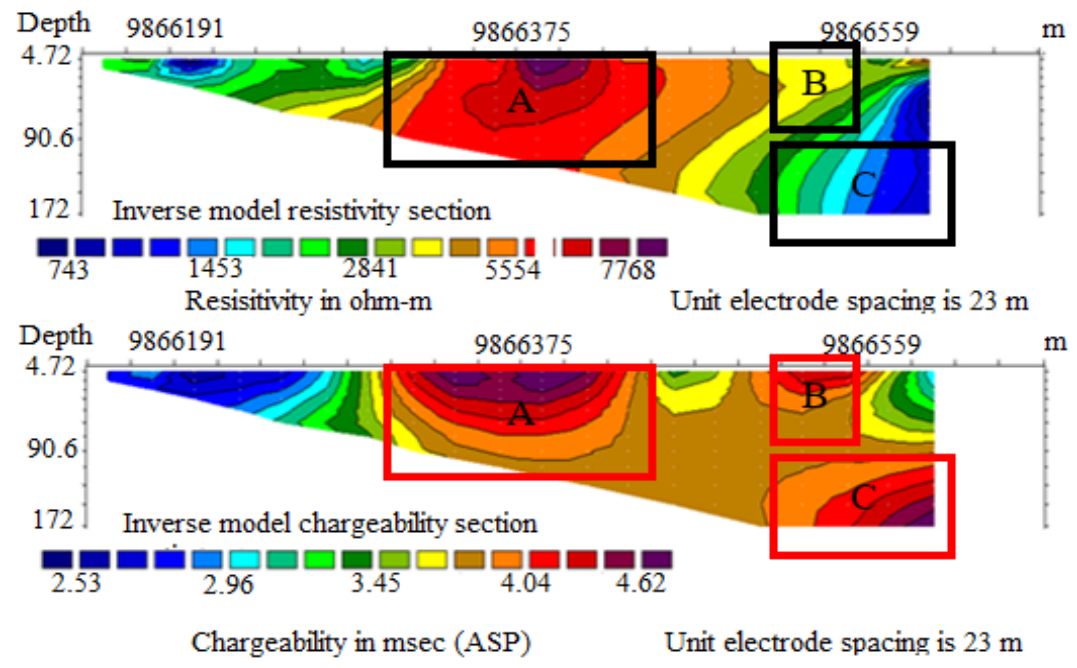

Figure 7: Line 1 Inversion model for resistivity and chargeability.

The survey line (Figure 7) began at $9866145\left(1^{\circ} 13^{\prime} 40^{\prime} \mathrm{S}\right)$ and ended at 9866592 (UTM X coordinates) ( $1^{\circ} 13$ '20" S, 34 $44^{\circ}$ '00" $\mathrm{E})$, and each division along the survey line is $23 \mathrm{~m}$ (electrode distance). It was observed (Figure 7 above) that there are 3 prominent chargeability anomalies along the survey line 1: $\mathrm{A}, \mathrm{B}$ and $\mathrm{C}$. In zone $\mathrm{A}$, the chargeability occurs around $138 \mathrm{~m}$ from the beginning of the survey line and its approximately $138 \mathrm{~m}$ in width. The anomaly begins at about $4.72 \mathrm{~m}$ below ground surface and extends to a depth of up to $90.6 \mathrm{~m}$. In zone B, chargeability anomaly occurs at a distance of $345 \mathrm{~m}$ from the beginning of the survey line 1 and its approximately $69 \mathrm{~m}$ wide. It begins at approximately $4.72 \mathrm{~m}$ below the ground and extends to a depth of $60.1 \mathrm{~m}$ below the ground level. In zone $\mathrm{C}$, the anomaly occurs at distance of $345 \mathrm{~m}$ from the beginning of the survey line 1 and its approximately $100 \mathrm{~m}$ wide. The anomaly occurs at depth $90.6 \mathrm{~m}$ and extends up to depth of $172 \mathrm{~m}$ below the ground surface. The high chargeability indicates the presence of disseminated minerals which include gold and sulphide minerals such as pyrite and chalcopyrite at zones A, B and C (in Figure 7).

The resistivity inversion model shows that the above mineralisation is hosted in rocks with high electrical resistance and in rocks with low electrical resistance. For instance, as seen in Figure 7, it is observed that ore A is hosted in rock with high electrical resistance, while ore zones $\mathrm{B}$ and $\mathrm{C}$ are hosted in rocks with low electrical resistance. A ground truthing exercise revealed that the zone with high resistive materials falls within an area with a huge quartz vein which extended up to almost the ground level.

The ground truthing exercise also revealed that the zone with low resistive rocks as indicated by resistivity model falls in an area dominated by banded iron formations (BIF) rocks (Figure 8B). 

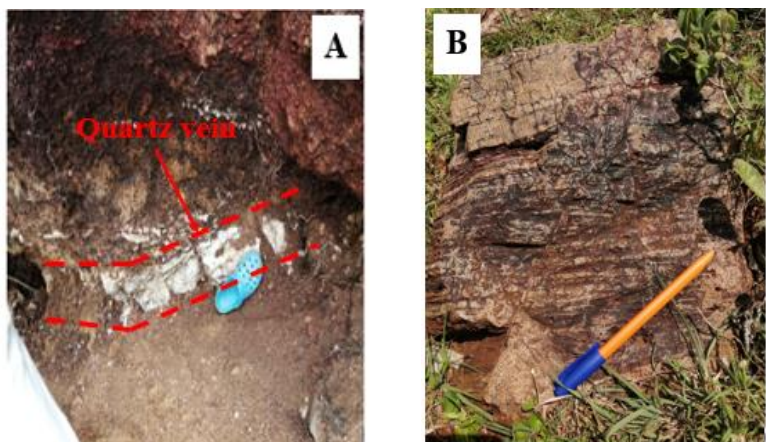

Figure 8: A) Quartz located along the survey line 1. B) Banded iron formation along the survey line 1 (Zone 2 and 3 ).

Inversion model along survey line 2 (L2)

Figure 9 is an inversion model for chargeability and resistivity data collected along survey line L2. This survey started at $1^{\circ}$ $14^{\prime} 30^{\prime}$ S S, 34 $48^{\circ}$ '00 E, and ended at $1^{\circ} 13^{\prime} 17^{\prime \prime}$ $\mathrm{S}, 34^{\circ} 48^{\prime} 10^{\prime \prime}$ E. Just as in survey line 1 , each division along the survey line is $23 \mathrm{~m}$. It was observed that there is a prominent chargeability anomaly along the survey line (the red and violet sections of the model). This chargeability starts at $368 \mathrm{~m}$ from the beginning of the survey line and its approximately $401 \mathrm{~m}$ in width. The anomaly begins at about $4.72 \mathrm{~m}$ below ground surface and extends to a depth of up to $127 \mathrm{~m}$ below the ground surface. The chargeability gives a strong evidence of existence of disseminated minerals as suggested above.

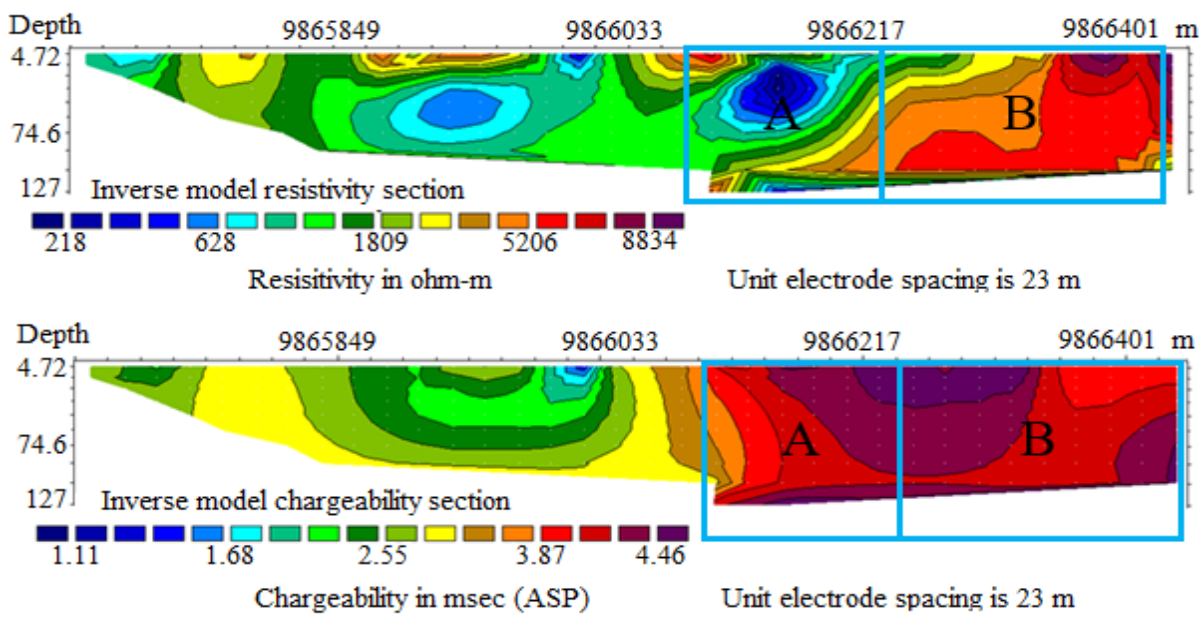

Figure 9: Line 2 Inversion model for the resistivity and chargeability.

The resistivity inversion model shows that the above mineralisation is hosted in rocks with high electrical resistance and in rocks with low electrical resistance. As seen in Figure 9, it is observed that at zone A the ore is hosted in rocks with low electrical resistance, while at zone $\mathrm{B}$ the ore is hosted in rocks with high electrical resistance. As mentioned earlier, the high electrical resistance rock may be quartz vein and the low electrical resistance rock may be banded iron formation. 


\section{Inversion model along survey line 3 (L3)}

Figure 10 shows an inversion model for chargeability and resistivity data collected along survey line L3. It is observed that at zone A the ore hosted in rocks with low electrical resistance, while at zone $\mathrm{B}$ the ore is hosted in rocks with high electrical resistance. The mapped sections (Figure $10 \mathrm{~A}$ and B) show similar resistivity to Figure $9 \mathrm{~A}$ and $\mathrm{B}$, which imply geological continuity of mineralised quartz vein and banded iron formation, respectively.

Figures 11 and 12 show resistivity and chargeability along survey lines 4 and 5, respectively. Along survey lines 4 (Figure 11), it is observed that zones of high IPchargeability are associated with high resistivity. These zones are delineated by letters A and B as shown in Figure 11. Similar result is observed along survey line 5 (Figure 12). From the figure, it is observed that zone $A$ has high chargeability and high resistivity. These results indicate the presence of disseminated minerals hosted (associated with high chargeability) in a rock with high electrical resistance (shown high resistivity) such as a massive quartz vein along survey lines 4 and 5 .

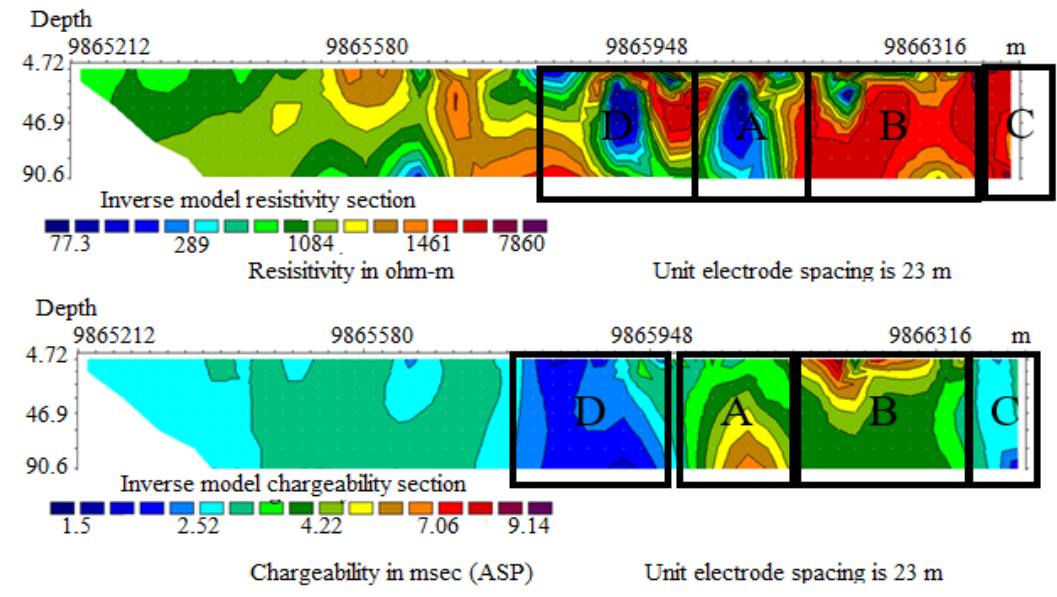

Figure 10: Line 3 Inversion model for the resistivity and chargeability.

\section{Inversion model along survey line 4 (L4)}

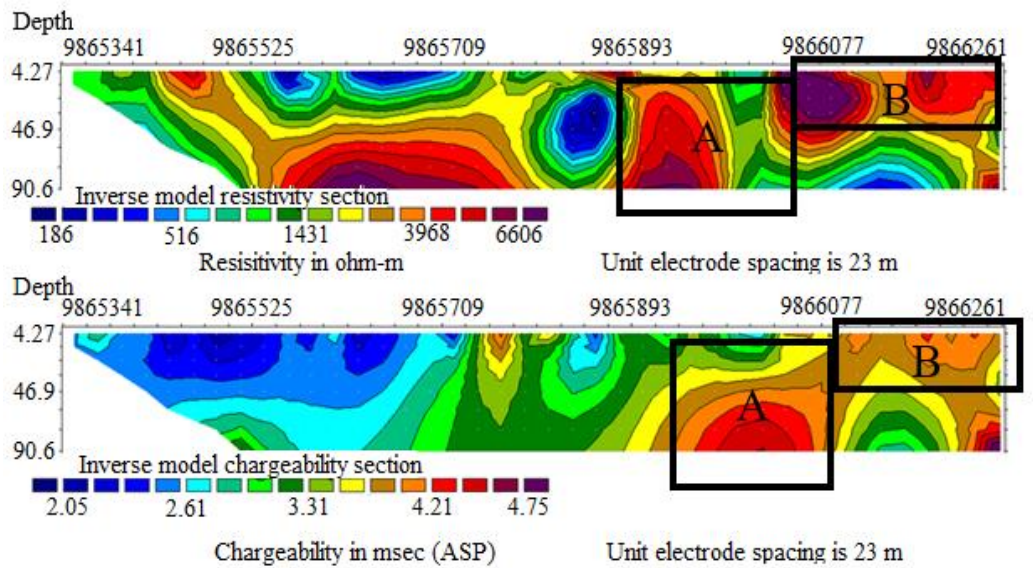

Figure 11: Line 4 Inversion model for the resistivity and chargeability. 


\section{Inversion model along survey line 5 (L5)}

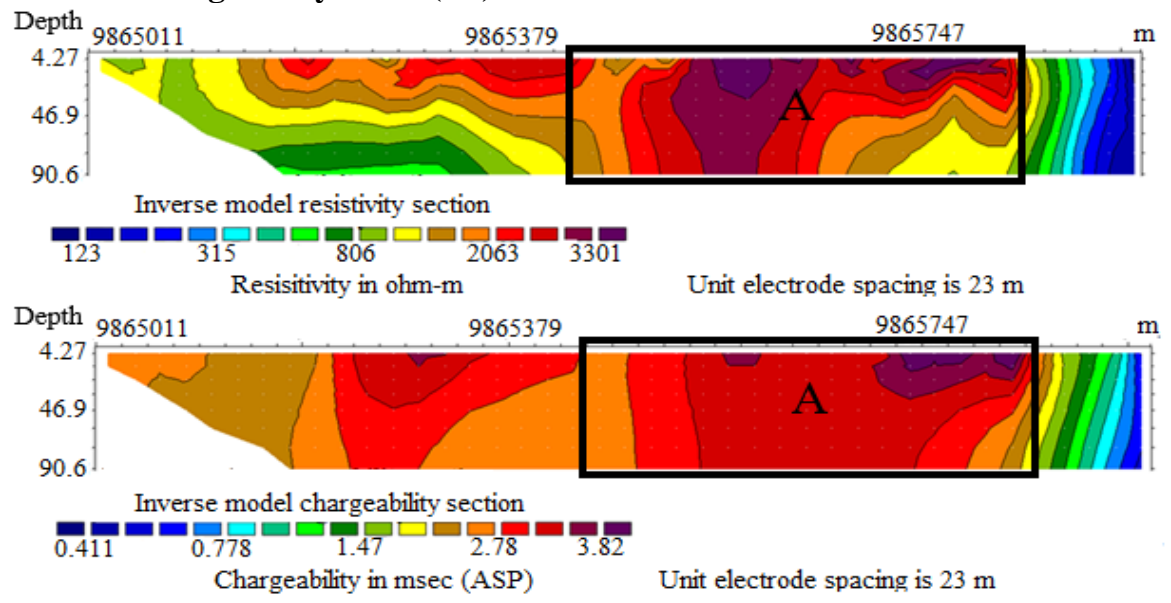

Figure 12: Line 5 Inversion model for the resistivity and chargeability.

\section{Hydrothermal alteration, geophysics and spectral properties signatures}

Hydrothermal fluids which result into mineralisation often change the properties of the host rocks (adjacent rocks) in a process called wall rock alteration (Suh 2009, Fon et al. 2012, Hallarou et al. 2020). The changes often involve the change of the host rock mineralogy such as formation of neo minerals (oxides, silica and sulphides). These minerals change the rock's physical properties which in turn result into distinct geophysical, geochemical and spectral signatures, and it is these signatures that are exploited by geoscientists in delineating areas of possible mineralisation (Fon et al. 2012, Moreira et al. 2016).

It is the contrast of the physical properties brought about by hydrothermal alterations that is revealed by the significant high IPchargeability and low resistivity anomalies in altered wall rocks when compared to unaltered and non-mineralised adjacent rocks as is the case of zones $\mathrm{B}$ and $\mathrm{C}$ along the survey line 1 and in zone A along survey lines 2 and 3 (Fon et al. 2012, Moreira et al. 2016). Photomicrograph section (Figure 13) of representative rock sample obtained from zone $\mathrm{B}$ along line survey line 1 shows disseminated gold particles together with pyrite (a sulphide mineral) hosted in a banded iron formation wall rock. As observed in the figure, gold was shown by $\mathrm{Au}$, pyrite by $\mathrm{Py}$ (the rectangular minerals in the specimen) and opaque minerals by Opq which could be iron oxides (hematite and/or magnetite).

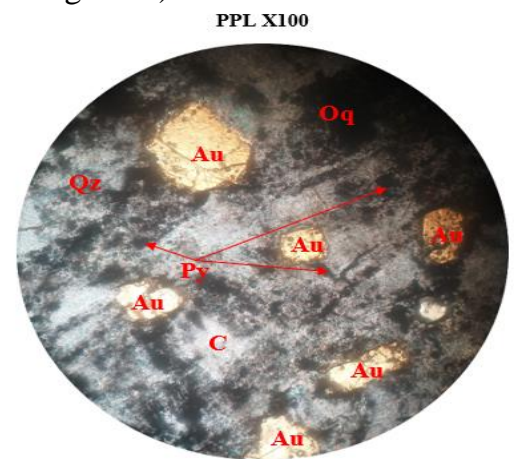

Figure 13: Photomicrograph (plane polarised light image, PPL) of banded iron formation rock obtained from a zone of high chargeability and low resistivity (zones 2 and 3 of survey line 1). The figure shows gold ( $\mathrm{Au})$, pyrite (Py) and opaque minerals (Opq). The mineral abbreviations follow Whitney and Evans (2010).

The contrast in physical properties may also be revealed by significant high resistivity and high IP-chargeability of the ore body relative to adjacent rocks which are non-mineralised as is 
the case of zone A along survey line 1, zone B along survey lines 2 and 3 and anomalies in encountered along survey lines 4 and 5 (Fon et al. 2012, Antonelli et al. 2019). This occurs especially when hydrothermal alteration involves silicification process where original rock minerals are replaced by silica associated minerals which may result in the formation of massive quartz veins (Fon et al. 2012, Han et al. 2016, Komori et al. 2017, Antonelli et al. 2019, Suyanto and Rugayya 2019). These quartz veins are associated with high electrical resistivity signatures (Fon et al. 2012, Han et al. 2016, Komori et al. 2017, Antonelli et al. 2019, Suyanto and Rugayya 2019).

Additionally, hydrothermal alteration is often associated with the formation of clay minerals that increase rock's electrical conductivity and have distinct spectral properties making them detectable by remote sensing data as is the case of this study (Galán and Ferrell 2013, Bloise et al. 2020, Fulignati 2020, Tangari et al. 2020). As such, the presence of these clay minerals accompanied by increased electrical conductivity (low electrical resistivity) may be an indication of mineralisation as is the case of this study. An example of these clay minerals is argillicpropylitic clay minerals which are often associated with low electrical resistivity anomalies and they are formed as a result of the reaction between host rock and hydrothermal fluids (Fon et al. 2012, Abbaszadeh and Hezarkhani 2013, Amer et al. 2016, Moreira et al. 2016). It is however, important to note that precipitation of adularia and quartz which usually accompany mineralisation of gold and silver commonly results into an increase of resistivity values exceeding $1000 \Omega \mathrm{m}$ (Fon et al. 2012, Hedenquist and Arribas 2017, Cortês et al. 2019, Reich et al. 2020, Xu et al. 2020). As such, gold mineralisation can be associated with both low and high resistivity depending on how and where the mineralisation process has occurred as is the case of Lolgorien (the study area) (Fon et al. 2012, Moreira et al. 2016).
The zones of high resistivity and low chargeability such as those shown in survey line 3 (Figure 10, zones C and D) are associated with massive barren quartz zones. A photomicrograph of a sample obtained from zone $\mathrm{C}$, survey line 3 proves this as shown in Figure 14.

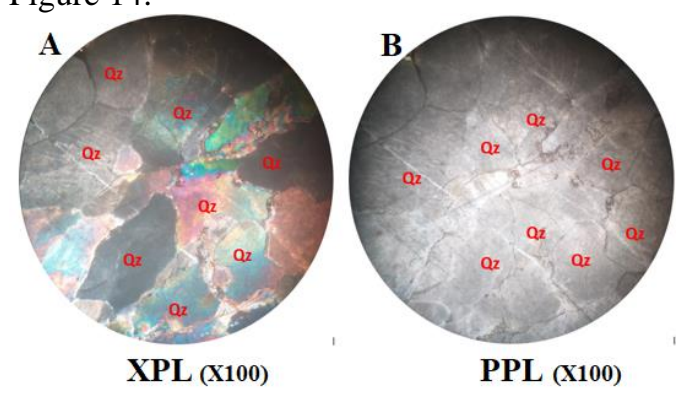

Figure 14: Photomicrograph of barren quartz vein obtained from zone of high resistivity and high chargeability.

\section{Conclusion}

Despite induced polarization and resistivity being applied in mineral exploration, their effectiveness in identification of mineralised zones is often improved by integrating other mineral exploration techniques such as remote sensing and geological studies. Integrating different mineral exploration techniques helps in reducing uncertainty that is often associated with mineral exploration. Integration of remote sensing and geophysics (chargeability and resistivity) techniques have helped in revealing some of the concealed subsurface mineralisation in Lolgorien. Remote sensed data helped map faults that acted as conduits for hydrothermal mineral occurrences. Therefore, collation of the mapped structures indicated the presences of gold and sulphide mineralization.

The IP and resistivity results illustrated near-surface up to $172 \mathrm{~m}$ depth gold and sulphide mineralisation. The high resistivity and high chargeability reflect disseminated mineralisation hosted in massive quartz veins as observed in zone A along survey line 1, zone B along survey lines 2 and 3 and anomalies in encountered along survey lines 4 and 5. The 
low resistivity and high IP-chargeability reflect disseminated mineralisation hosted in altered wall rocks such as the case of zones $B$ and $C$ along the survey line 1 and zone $\mathrm{A}$ along survey lines 2 and 3 . The altered wall rocks are the banded iron formations and the mineralisation is associated with gold, pyrite and chalcopyrite. The positive correlation between resistivity and chargeability (specifically, high resistivity and high chargeability) and the negative correlation between these two factors (specifically, low resistivity and high chargeability) suggest that not only the quartz veins found in Lolgorien are mineralised but also altered adjacent wall rock (banded iron formation) to some extent.

\section{Acknowledgement}

This research article is part of the first author's Ph.D. work and was funded by the African Union through the Pan-African University, Life and Earth Sciences Institute (including Health and Agriculture), University of Ibadan, Nigeria (PAULESI).

\section{References}

Abbaszadeh M and Hezarkhani A 2013 Enhancement of hydrothermal alteration zones using the spectral feature fitting method in Rabor area, Kerman, Iran. Arab. J. Geosci. 6(6): 1957-1964.

Abedi M and Norouzi GH 2012 Integration of various geophysical data with geological and geochemical data to determine additional drilling for copper exploration. $J$. Appl. Geophys. 83: 35-45.

Akech NO, Omuombo CA and Masibo M 2013 General geology of Kenya. Dev. Earth Surf. Proc. 16: 3-10.

Amer R, El Mezayen A and Hasanein M 2016 ASTER spectral analysis for alteration minerals associated with gold mineralisation. Ore Geol. Rev. 75: 239-251.

Antonelli F, Stevanato R, Maximilian FU and Abreu GC 2019 Resistivity and induced polarization applied to epithermal gold deposit in the Torre Target, at Castro BasinPR.

Ariyibi EA 2011 Integrated geochemical and geophysical approach to mineral prospecting-a case study on the basement complex of Ilesa Area, Nigeria. Adv. Dat. Methods, Models Appl. Geosci. Rijeka: InTech. 71-92.

Auken E, Pellerin L, Christensen NB and Sørensen K 2006 A survey of current trends in near-surface electrical and electromagnetic methods. Geophys. 71(5): G249-G260.

Bloise A, Cannata CB and Rosa RD 2020 Hydrothermal Alteration of Etna ash and implications for Mars. Minerals 10(5): 450.

Cortês AR, Moreira CA, Paes RA and Veloso DI 2019 Geophysical and metalogenetic modelling of the copper occurrence in Camaquã Sedimentary Basin, Brazilian Southern. Pure Appl. Geophys. 176(11): 4955-4968.

Fon AN, Che VB and Suh CE 2012 Application of electrical resistivity and chargeability data on a GIS platform in delineating auriferous structures in a deeply weathered lateritic terrain, eastern Cameroon. Int. J. Geosci. 3(05): 960.

Fulignati P 2020 Clay minerals in hydrothermal systems. Minerals 10(10): 919.

Gaafar I 2015 Integration of geophysical and geological data for delimitation of mineralised zones in Um Naggat area, Central Eastern Desert, Egypt. NRIAG J. Ast. Geophys. 4(1): 86-99.

Galán E and Ferrell R 2013 Genesis of clay minerals. Dev. Clay Sci. 5: 83-126.

Hallarou MM, Konaté M, Olatunji AS, Ahmed Y, Ajayi FF and Abdul RM 2020 Re-Os ages for the Kourki porphyry $\mathrm{Cu}-\mathrm{Mo}$ deposits, North West Niger (West Africa): geodynamic implications. Euro. J. Environ. Earth Sci. 1(4).

Han T and Nelson J 2015 Mapping hydrothermally altered rocks with Landsat 8 imagery: A case study in the KSM and Snow field zones, northwestern British 
Ombiro et al. - Integration of geophysics and remote sensing techniques in mapping zones ...

Columbia. Geol. Fieldwork 2014. 2015 (1):103-112.

Han MH, Shin SW, Park S, Cho SJ and Kim JH 2016 Induced polarization imaging applied to exploration for low-sulfidation epithermal $\mathrm{Au}-\mathrm{Ag}$ deposits, Seongsan mineralised district, South Korea. J. Geophys. Eng. 13(5): 817-823.

Hedenquist JW and Arribas R 2017 Epithermal ore deposits: first-order features relevant to exploration and assessment. Min. Resour. Discover 1: 47-50.

Henckel J, Poulsen K, Sharp T and Spora P 2016 Lake victoria goldfields. Episodes 39(2): 135-154.

Ichang'i D and MacLean W 1991 The Archean volcanic facies in the Migori segment, Nyanza greenstone belt, Kenya: stratigraphy, geochemistry and mineralisation. J. Afr. Earth Sci. 13(3/4): 277-290.

Komori S, Masaki Y, Tanikawa W, Torimoto J, Ohta Y, Makio M, Maeda L, Ishibashi JI, Nozaki T, Tadai O and Kumagai H 2017 Depth profiles of resistivity and spectral IP for active modern submarine hydrothermal deposits: a case study from the Iheya North Knoll and the Iheya Minor Ridge in Okinawa Trough, Japan. Earth, Planets Space 69(1): 114.

Lowrie W and Fichtner A 2020 Fundamentals of geophysics, Cambridge University Press.

Moreira CA, Borssatto K, Ilha LM, Santos SF and Rosa FT 2016 Geophysical modeling in gold deposit through DC resistivity and induced polarization methods. REM-Int. Eng. J. 69(3): 293-299.

Murray-Hughes R 2007 Geological Survey of Lolgorien Area. Mines and Geology Department, Nairobi.

Ogungbemi OS, Amigun JO and Olayanju GM 2018 Geophysical characterization of mineralisation potential of eastern parts of Ife-Ijesha Schist-Belt, southwestern Nigeria. Int. J. Sci. Technol. Res. 7: 21-27.

Ombiro S and Akisa D 2016 The complexity and uncertainty involved in mine planning and design. Annual proceedings of Sustainable Research and Innovation Conference. 250-252.

Reich M, Román N, Barra F and Morata D 2020 Silver-rich chalcopyrite from the active Cerro Pabellón geothermal system, Northern Chile. Minerals 10(2): 113.

Shackleton R 1946 Geology of the Migori gold belt. Geol. Surv. Kenya. 10.

Suh C 2009 Sulphide microchemistry and hydrothermal fluid evolution in quartz veins, Batouri gold district (southeast Cameroon). J. Cameroon Acad. Sci. 8(1): 19-30.

Sultan SA, Mansour SA, Santos FM and Helaly AS 2009 Geophysical exploration for gold and associated minerals, case study: Wadi El Beida area, South Eastern Desert, Egypt. J. Geophys. Eng. 6(4): 345356.

Suyanto I and Rugayya S 2019 Identification of hydrothermal deposit mineralised zones using the induced polarization method in Kasihan Area, Pacitan, East Java. J. Phys. Conf. Ser. 1242(1): 012046.

Tangari AC, Marinangeli L, Scarciglia F, Pompilio L and Piluso E 2020 Volcanic holocrystalline bedrock and hydrothermal alteration: a terrestrial analogue for Mars. Minerals 10(12): 1082.

Vallee MA, Smith RS and Keating P 2011 Metalliferous mining geophysics-State of the art after a decade in the new millennium. Geophys. 76(4): W31-W50.

Waswa AK 2015 Integration of geological mapping and remote sensed studies for the discovery of iron-ore mineralisation in Mutomo-Ikutha area, SE Kenya. PhD thesis, University of Nairobi.

Whitney DL and Evans BW 2010 Abbreviations for names of rock-forming minerals. Am. Mineral. 95(1): 185-187.

Xu S, Xu F, Hu X, Zhu Q, Zhao Y and Liu S 2020 Electromagnetic characterization of epithermal gold deposits: A case study from the Tuoniuhe gold deposit, Northeast China. Geophys. 85(3): B49-B62. 